\section{Genetic disturbances in patients with bodily isomerism from a single center: clinical implications of affected genes and potential impact of ciliary dyskinesia}

\author{
Rohit S. Loomba, ${ }^{1}$ Peter C. Frommelt, \\ Robert H. Anderson ${ }^{2}$
}

'Children's Hospital of Wisconsin/Medical College of Wisconsin, Milwaukee, WI, USA; ${ }^{2}$ Institute of Genetics, Newcastle Upon Tyne, UK

\section{Abstract}

So-called heterotaxy or isomerism is characterized by abnormal lateralization and malformations of the bodily organs. The mechanism is unclear, although there is growing evidence that ciliary dyskinesia is involved. We reviewed genetic findings from patients with isomerism to determine if affected genes were known to be associated with isomerism and ciliary dyskinesia and determine associations between genotype and clinical findings. We identified patients with isomerism cared for over a 16year period. Characteristics were compared between those with and without identified mutations. A total of 83 patients with isomerism were identified. Of those who had genotyping, 14/27 had mutations identified, most frequently involving the CFC1 and NODAL genes. Specific mutations were associated with clinical findings, with NODAL mutations often portending need for increased clinical support. Genes associated with isomerism and/or ciliary dyskinesia were identified in the cohort. Specific gene mutations may help predict clinical course.

\section{Introduction}

Isomerism is a unique clinical entity in which there is mirror imagery of the thoracic organs within the same individual, which has also been characterized by the more ambiguous term heterotaxy. ${ }^{1,2}$ As a result, both bronchuses are either long and hyparterial, making them morphologically left, or short and eparterial, meaning that they are morphologically right. The lungs usually share the same morphological sidedness as the bronchuses, with either bilobed or trilobed lungs being present bilaterally. ${ }^{3-7}$ In the heart, isomerism is unequivocally present with the atrial appendages. The atrial appendages are the most constant of the atrial morphological features, meaning that they can be used, from the stance of the heart, for segregating isomerism into its right and left isomeric subsets. ${ }^{8-10}$ Examination of large numbers of autopsied specimens shows that this is a more reliable method of segregating heterotaxy than use of splenic anatomy. ${ }^{11,12}$ Isomerism in the heart, furthermore, is also found in the conduction system, with sinus nodes known to be bilaterally present in the setting of right isomerism..$^{13}$ Twin atrioventricular nodes may also be present in either subset, this potentiating in many cases to arrhythmias. ${ }^{14,15}$ The arrangement of the abdominal organs, however, although markedly different from the usual or mirrorimages lateralized arrangements, shows minimal evidence of isomerism. ${ }^{8}$

The mechanism underscoring an isomeric formation of the thoracic organs is unclear, although emerging data indicates that isomerism may be the result of ciliary dyskinesia, with dyskinesia being found in at least twofifths of afflicted patients. ${ }^{16}$ While the ciliary ultrastructure can be normal, the ciliary beat is abnormal. This may alter leftward differentiation of embryonic flow at the node during early development. Additionally, formation of nonmotile cilia may impact intracellular signaling, which could lead to functional abnormalities not only during embryogenesis, but also later in life. ${ }^{17,18}$ In patients with isomerism, the presence of ciliary dyskinesia can result in significant sinupulmonary disease and may also mediate splenic dysfunction, increasing the risk of bacteremia and thrombocytosis. ${ }^{19-21}$ Hepatic, renal, and central nervous system malformations and dysfunction may also be a result of ciliary dyskinesia. ${ }^{20,22-32}$

Ciliary dyskinesia and isomerism are now known to be associated with specific genetic mutations, some being common to both. Genes such as Lefty 1 and Pitx2 were initially demonstrated to be associated with isomerism, with additional genes subsequently identified. ${ }^{33,34}$ The primary aim of this study, therefore, was to determine if mutations were present in a cohort of patients from a single center known to have isomeric features, and to quantify what proportion of affected genes have been previously associated with either isomerism, ciliary dyskinesia, or both. Additionally, we sought to assess the association of specific affected genes with anatomic and clinical outcomes.

\section{Materials and Methods}

\section{Selection of patients}

We reviewed medical records of all patients cared for since 1998 with isomerism at Children's Hospital of Wisconsin. This was the
Correspondence: Rohit S. Loomba, Children's Hospital of Wisconsin/Medical College of Wisconsin, 9000 Wisconsin Avenue, Milwaukee, WI, 53202 USA.

E-mail: loomba.rohit@gmail.com

Key words: CFC1; NODAL; heterotaxy.

Ethical standards: this study was done in accordance with the ethical standards of the institutional research committee and with the 1964 Helsinki declaration and its later amendments. As data from human patients was utilized, institutional review board (IRB) approval was obtained. Individual patient consent was waived by the IRB as this is a retrospective study.

Conflict of interest: there are no conflict of interest to disclose for any of the authors.

Received for publication: 17 February 2016.

Revision received: 4 August 2016.

Accepted for publication: 27 August 2016.

This work is licensed under a Creative Commons Attribution NonCommercial 4.0 License (CC BYNC 4.0).

(C) Copyright R.S. Loomba et al., 2016

Licensee PAGEPress, Italy

Cardiogenetics 2016; 6:5818

doi:10.4081/cardiogenetics.2016.5818

year that electronic medical records were implemented at our institution. The dataset included patients born in or after 1998, as well as those born earlier who transitioned their care to our heart center after 1998. Patients were identified through multiple searches so as to ensure the highest yield of patients. Medical records, medical billing data, and the echocardiography database, cardiac catheterization database, cardiothoracic surgical database were queried for isomerism, heterotaxy, asplenia, multiple spleens, and polysplenia. The resulting lists of patients were then combined, and redundant entries removed. The remaining patients were reviewed, and included if they had both congenital heart disease and recognized features of isomerism. Congenital heart disease was defined as any intracardiac lesion and/or an abnormality of venous return to the heart. We considered isomerism to be present when there was a cardiovascular malformation in addition to evidence of abnormal arrangement of the abdominal organs, including the spleen, or overt evidence of pulmonary isomerism. The diagnosis of right or left isomerism was based on our subsequent review of the clinical and anatomic data.

Next, we identified which patients had undergone genetic testing other than a chromosomal karyotype. These included heterotaxy gene panels conducted by polymerase chain reaction, ciliopathy gene panel conducted by 
polymerase chain reaction, as well as hybridized microarray.

The details of cardiac anatomy were obtained primarily from the echocardiographic findings, although data from computed tomographic, magnetic resonance, and cardiac catheterization studies was also available for some patients. The splenic status was based on findings from abdominal ultrasonography. At our institution, genetic evaluation of patients with isomerism is done on a case by case basis. The proposed methodology was approved by the Institutional Review Board at our institution.

\section{Characteristics of the cohort}

For our baseline analysis, we categorized the cardiac diagnoses into primary and secondary lists. The primary diagnosis was the lesion considered to be the most hemodynamically significant, while the secondary diagnosis included other associated lesions. For instance, if a patient had an atrioventricular septal defect with common atrioventricular valvar orifice, double outlet right ventricle, and an interrupted inferior caval vein, then the atrioventricular septal defect was coded as the primary diagnosis, with double outlet right ventricle and interrupted inferior caval vein listed as secondary diagnoses. If a patient simply had interruption of the inferior caval vein, then this was coded as the primary diagnosis. It was implicit that those with bilateral superior caval veins of necessity had a left-sided superior caval vein.

\section{Inferences regarding presence of isomeric right or left atrial appendages}

The intracardiac features considered to indicate presence of isomeric right as opposed to left atrial appendages were assessed independently by two authors (RL and RHA), with cognizance taken also of the findings in the other systems of organs. These included, but were not limited to, overall cardiac anatomy, venoatrial connections, and pulmonary and splenic anatomy. The results of the independent assessments were then compared, and any differences discussed, with a consensus being reached by both authors regarding the likely presence of isomeric right as opposed to left atrial appendages. In some instances, the assessors agreed that there was probably usual arrangement of the atrial appendages, despite the presence of known bronchial isomerism.

An aggregate of several features was used to help determine whether isomerism of the right or left atrial appendages was present. Interruption of the inferior caval vein, for example, is known to be associated more with isomerism of the left atrial appendage. In contrast, absence of the coronary sinus and totally anom- alous pulmonary venous connection are uniformly present in the setting of right isomerism. The presence of multiple spleens, or absence of a spleen, was also used to help segregate the subsets of isomerism. The bronchial branching pattern was also used when available.

\section{Genetic testing}

General microarray testing was done utilizing an array done within the institution itself. Whole genome array-based analysis was done to identify losses or gains of DNA variants (copy number variants) within the human genome using the Affymetrix Cytoscan HD array. Array data was then analyzed using Affymetrix Chromosome Analysis Suite. The array contains 2,696,550 genetic markers, including 743,305 single nucleotide polymorphisms and approximately 1,953,246 non-polymorphic markers for the detection of copy number variants. When the array identified a duplication less than or equal to $500 \mathrm{~kb}$ or a deletion than or equal to $200 \mathrm{~kb}$, quantitative polymerase chain reaction was used to confirm losses or gains. For each segment confirmed with quantitative polymerase chain reaction, an Applied Biosystems TaqMan Gene Copy Number Assay was used. Assay data was analyzed using the Applied Biosystems CopyCaller Software. Each assay is run with positive controls and a non-template control.

Heterotaxy panels were run by Prevention Genetics utilizing a Next General sequencing panel. Full coding regions plus 20 base pairs of non-coding DNA flanking each exon were sequenced for areas of interest. The following genes were sequenced: $A C V R 2 B, A N K S 6$, CCDC103, CCD11, CCDC114, CCDC39, CCDC40, DNAAF1, DNAAF2, DNAAF3, DNAH11, DNAH5, DNAI1, DNAI2, DNAL1, FOXH1, GDF1, HEATR2, INVS, LEFTY2, LRRC6, NKX2-5, NME8, NODAL, and ZIC3

\section{Statistical analysis}

To identify patients who differed from each other in regard to the arrangement of their organs, we compared the findings between patients as being likely to have isomerism of the right or left atrial appendages as opposed to usual or mirror-imaged atrial arrangement, using chi-squared analysis for categorical data and independent T-tests or Mann-Whitney-U tests where appropriate. Characteristics were also compared between those shown to have isomerism of the right or left bronchuses.

Characteristics, including intracardiac and extracardiac anomalies, were compared between those with and without an identified genetic mutation using chi square analysis for descriptive variables. Continuous variables were compared using a Mann-Whitney-U test. On this basis, patients were categorized into groups of NODAL mutation only, CFC1 mutation only, CFC1 combined with NODAL muta- tion, mutation in another gene, or no mutation. These groups were then compared by chi square analysis for descriptive variables, and analysis of variance for continuous variables.

\section{Results}

A total of 83 subjects met criteria for inclusion with the diagnosis of isomerism. All of these patients had karyotypes done. Of these, $27(32.5 \%)$ had undergone genetic analysis other than a karyotype as well (Figure 1). This additional analysis consisted of a general microarray in all 27 of these patients. 8 of these patients also had a heterotaxy panel sent in addition to the karyotype and general microarray. Review of genetic testing identified known mutations in 14 (51.9\%) of the 27 patients (Table 1).

\section{Clinical characteristics}

When we compared characteristics between those with and without an identified mutation, those with an identified mutation were more likely to have bilaterally right bronchuses (Table 1). There was no statistically significant difference, however, in the inferred morphology of the atrial appendages, or cardiac anatomic features.

The need for mechanical ventilatory support before initial cardiac surgical palliation and the number of days of postoperative mechanical ventilatory support after initial cardiac palliation was higher in those with an identified mutation (Table 2). Mechanical ventilatory support prior to initial cardiac palliation was required in 6 (50\%) of those with an identified mutation, but in only 1 (9\%) of those without

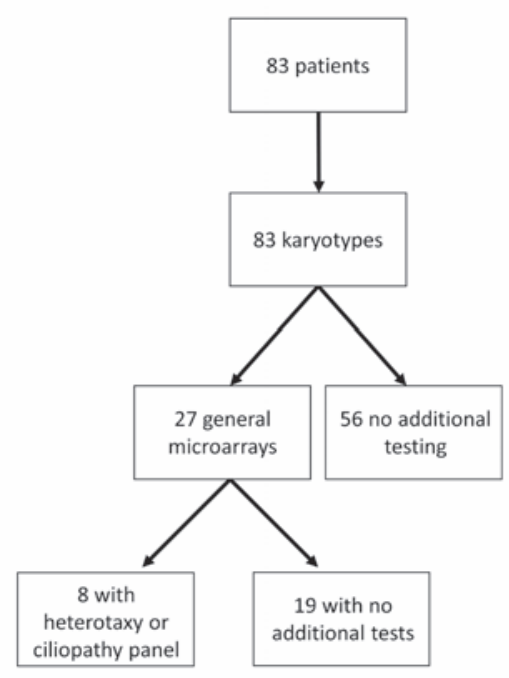

Figure 1. Flowchart illustrating testing done in the cohort. 
$(\mathrm{P}=0.033)$. Median duration of postoperative mechanical ventilatory support after initial cardiac palliation was 7.5 days in those with an identified mutation, and 3 days in those without $(\mathrm{P}=0.045)$. Clinical outcomes of bacteremia, recurrent otitis media, recurrent pneumonia, chronic lung disease, asthma, need for supplemental oxygen at home, need for extracorporeal membrane oxygenation at home, and mortality did not differ between the groups (Table 2).

\section{Genetic characteristics}

By combining the positive karyotypes and the microarrays, a total of 13 genes were noted to have mutations. Of the 13 genes, 10 (76.9\%) have been demonstrated to have associations with either ciliary abnormalities or isomerism in mice, 8 (61.5\%) with ciliary abnormalities, and $8(61.5 \%)$ with isomerism. Of these 13 genes, 5 (38.5\%) have been demonstrated to be associated with ciliary abnormalities or isomerism in humans, 2 (15.4\%) with ciliary abnormalities, and 3 (23.1\%) with isomerism (Table 3).

A CFC1 mutation was present in 5 (35.7\%) of all patients with identified mutations, while a NODAL mutation was present in $3(21.4 \%)$, making these the two most commonly affected genes in our cohort. In 2 (14.3\%) patients, both CFC1 and NODAL were mutated (Table 4). When the cohort was segregated into subgroups of $C F C 1$ mutation only, NODAL mutation only, both CFC1 and NODAL mutation, other affected gene, or no mutation, there were statistically significant differences noted between the groups. Those with a NODAL mutation only, CFC1 mutation only, other mutation, or no mutation tended to be associated with right isomerism, while those with

Table 1. Patient characteristics based on isomerism subtype.

\begin{tabular}{|c|c|c|c|}
\hline & $\begin{array}{l}\text { Patients with no identified } \\
\text { mutation }(n=13)\end{array}$ & $\begin{array}{l}\text { Patients with identified mutation } \\
\qquad(\mathrm{n}=14)\end{array}$ & P-value \\
\hline Common atrioventricular junction & $9(69.2)$ & $9(64.3)$ & 0.785 \\
\hline Double outlet right ventricle & $5(38.5)$ & $4(28.6)$ & 0.586 \\
\hline Bilateral superior caval veins & $6(46.2)$ & $7(50.0)$ & 0.842 \\
\hline $\begin{array}{l}\text { Left sided superior caval vein } \\
\text { Interruption of the inferior caval vein }\end{array}$ & $\begin{array}{l}7(53.8) \\
4(30.8)\end{array}$ & $\begin{array}{l}8(57.1) \\
3(21.4)\end{array}$ & $\begin{array}{l}0.863 \\
0.580\end{array}$ \\
\hline $\begin{array}{l}\text { Atrioventricular connections } \\
\text { Mixed } \\
\text { Double inlet }\end{array}$ & $\begin{array}{l}8(61.5) \\
5(38.5)\end{array}$ & $\begin{array}{l}10(71.4) \\
4(28.6)\end{array}$ & 0.557 \\
\hline $\begin{array}{l}\text { Ventriculoarterial connections } \\
\text { Concordant } \\
\text { Discordant }\end{array}$ & $\begin{array}{l}9(69.2) \\
4(30.8)\end{array}$ & $\begin{array}{l}11(78.6) \\
3(21.4)\end{array}$ & 0.580 \\
\hline Inferred morphology of the atrial appendages & $12(92.3)$ & $11(78.6)$ & 0.315 \\
\hline $\begin{array}{l}\text { Bronchial morphology } \\
\text { Bilaterally left } \\
\text { Bilaterally right } \\
\end{array}$ & $\begin{array}{l}5(38.5) \\
8(61.5)\end{array}$ & $\begin{array}{c}0(0) \\
12(100)\end{array}$ & 0.016 \\
\hline $\begin{array}{l}\text { Splenic anatomy } \\
\text { Absence of a spleen } \\
\text { Multiple spleens } \\
\text { Solitary spleen }\end{array}$ & $\begin{array}{l}7(53.8) \\
4(30.8) \\
2(15.4)\end{array}$ & $\begin{array}{l}8(57.1) \\
2(14.3) \\
4(28.6)\end{array}$ & 0.505 \\
\hline $\begin{array}{l}\text { Stomach and liver sidedness } \\
\text { Left sided stomach with right sided liver } \\
\text { Right sided stomach with left sided liver } \\
\text { Left or right sided stomach with midline liver }\end{array}$ & $\begin{array}{l}1(8.3) \\
9(75.0) \\
2(16.7)\end{array}$ & $\begin{array}{l}3(25.0) \\
4(33.3) \\
5(41.7)\end{array}$ & 0.122 \\
\hline Intestinal malrotation & $9(69.2)$ & $9(64.3)$ & 0.785 \\
\hline Need for gastrostomy tube & $4(30.8)$ & $5(35.7)$ & 0.785 \\
\hline Chronic arrhythmia & $8(61.5)$ & $7(50.0)$ & 0.547 \\
\hline Need for pacemaker & $3(23.1)$ & $0(0)$ & 0.057 \\
\hline Prenatal diagnosis & $10(76.9)$ & $13(92.9)$ & 0.244 \\
\hline $\begin{array}{l}\text { Repair status at most recent follow-up } \\
\text { Biventricular repair } \\
\text { Univentricular repair }\end{array}$ & $\begin{array}{l}5(38.5) \\
8(61.5)\end{array}$ & $\begin{array}{l}5(35.7) \\
9(64.3)\end{array}$ & 0.883 \\
\hline Bacteremia & $2(15.4)$ & $4(28.6)$ & 0.410 \\
\hline Recurrent otitis media & $1(7.7)$ & $0(0.0)$ & 0.290 \\
\hline Recurrent pneumonia & $0(0.0)$ & $0(0.0)$ & -- \\
\hline Chronic lung disease & $1(7.7)$ & $3(21.4)$ & 0.315 \\
\hline Asthma & $2(15.4)$ & $0(0.0)$ & 0.127 \\
\hline Need for supplemental oxygen at home & $6(46.2)$ & $3(21.4)$ & 0.173 \\
\hline Need for extracorporeal membrane oxygenation & $3(23.1)$ & $2(14.3)$ & 0.557 \\
\hline Mortality & $3(23.1)$ & $5(35.7)$ & 0.472 \\
\hline Age at death (days) & 154 (8 to 1,432$)$ & 189 (42 to 235$)$ & 0.306 \\
\hline Follow-up times (years) & $2.0(0.5$ to 3.8$)$ & $1.6(0.2$ to 13$)$ & 0.323 \\
\hline
\end{tabular}

Frequencies presented as absolute number (percentage) while numeric values are presented as median (minimum to maximum). The denominator for some variables is lower than the total due to missing data. 
both a Nodal and CFC1 mutation tended to be associated with left isomerism $(\mathrm{P}=0.006)$. Those with a NODAL mutation only, or CFC1 mutation only, tended to have a right-sided stomach with left-sided liver, while those with a mutation in another gene tended to have right or left sided stomachs with midline livers $(\mathrm{P}=0.038)$. Arrhythmias also differed between the various mutations. Supraventricular tachycardia was more commonly noted in those with a NODAL mutation only, CFC1 mutation only, and those with mutations in other genes, but was not present in those with both a NODAL and CFC1 mutation $(\mathrm{P}=0.024)$. Sinus nodal dysfunction was most frequently noted in those with only a $C F C 1$ mutation, while ectopic atrial tachycardia was most frequently noted in those with mutations in other genes $(\mathrm{P}=0.024)$.

A mutation in NODAL only was associated with increased length of hospitalization for initial cardiac palliation, with a median of 134 days. Those with a mutation in both NODAL and $C F C 1$ had an even greater length of hospitalization for initial cardiac palliation, with a median of 177 days $(\mathrm{P}=0.031)$. Mutation in
NODAL only was also associated with increased length of hospitalization for second cardiac intervention, with a median of 134 days. Those with a mutation in both NODAL and $C F C 1$ had an even greater length of hospitalization for second cardiac palliation, with a median of 235 days $(\mathrm{P}=0.023)$. Those with a mutation in NODAL, CFC1, or both NODAL and $C F C 1$, also required increased length of mechanical ventilatory support after second cardiac palliation $(\mathrm{P}=0.030)$.

Table 2. Surgical data of cohort based on isomerism subtype.

\begin{tabular}{|c|c|c|c|}
\hline & $\begin{array}{l}\text { ents with no identified } \\
\text { mutation }(\mathrm{n}=13)\end{array}$ & $\begin{array}{l}\text { Patients with identified } \\
\text { mutation }(\mathrm{n}=14)\end{array}$ & P-value \\
\hline Underwent first surgery & $11(84.6)$ & $12(85.7)$ & 0.936 \\
\hline Age at first surgery (days) & $9(4$ to 871$)$ & $12.5(0$ to 822$)$ & 0.469 \\
\hline Need for mechanical ventilation during hospitalization for, but before, first surgery & $1(9.1)$ & $6(50.0)$ & 0.033 \\
\hline Number of days of mechanical ventilation after first surgery & $3(0$ to 8$)$ & $7.5(0$ to 114$)$ & 0.045 \\
\hline Number of days chest left open postoperatively after first surgery & $0(0$ to 6$)$ & $1(0$ to 28$)$ & 0.110 \\
\hline Total length of hospitalization for first surgery (days) & $42(5$ to 154$)$ & $94(7$ to 235$)$ & 0.166 \\
\hline Underwent second surgery & $8(61.5)$ & $9(64.3)$ & 0.883 \\
\hline Age at second surgery (days) & 155 (103 to 963$)$ & $158(15$ to 280$)$ & 0.547 \\
\hline Need for mechanical ventilation during hospitalization for, but before, second surgery & $1(12.5)$ & $3(33.3)$ & 0.312 \\
\hline Number of days of mechanical ventilation after second surgery & $2(0$ to 9$)$ & $4(0$ to 95$)$ & 0.223 \\
\hline Number of days chest left open postoperatively after second surgery & $0(0$ to 6$)$ & $0(0$ to 9$)$ & 0.418 \\
\hline Total length of hospitalization for second surgery (days) & 44.5 (14 to 154$)$ & 41.5 (8 to 235$)$ & 0.733 \\
\hline Underwent third surgery & $0(0.0)$ & $2(15.4)$ & 0.141 \\
\hline Age at third surgery (days) & -- & 633.5 (193 to 1074$)$ & -- \\
\hline Need for mechanical ventilation during hospitalization for, but before, third surgery & -- & $1(50.0)$ & -- \\
\hline Number of days of mechanical ventilation after third surgery & -- & $0(0$ to 0$)$ & -- \\
\hline Number of days chest left open postoperatively after third surgery & - & $0(0$ to 0$)$ & -- \\
\hline Total length of hospitalization for third surgery (days) & -- & 26 (11 to 41$)$ & -- \\
\hline
\end{tabular}

Table 3. Genes identified in cohort and their association with isomerism and ciliary dyskinesia.

\begin{tabular}{|c|c|c|c|c|c|}
\hline Gene & $\begin{array}{l}\text { Associated with ciliary } \\
\text { abnormalities } \\
\text { in mice }\end{array}$ & $\begin{array}{l}\text { Associated with } \\
\text { isomerism } \\
\text { in mice }\end{array}$ & $\begin{array}{l}\text { Associated } \\
\text { with cilia } \\
\text { in humans }\end{array}$ & $\begin{array}{l}\text { Associated with } \\
\text { isomerism } \\
\text { in humans }\end{array}$ & $\begin{array}{c}\text { Inheritance in } \\
\text { humans }\end{array}$ \\
\hline NODAL & Yes & Yes & No & Yes & $\mathrm{Ad}$ \\
\hline CFCl & Yes & Yes & No & Yes & $\mathrm{Ar}$ \\
\hline ССDC39 & Yes & Yes & Yes & No & -- \\
\hline DNAH11 & Yes & Yes & Yes & No & -- \\
\hline$N K X 2.5$ & Yes & No & No & No & -- \\
\hline TBXI & No & Yes & No & No & -- \\
\hline ZIC3 & Yes & Yes & No & Yes & $\mathrm{Xl}$ \\
\hline$D N A A F$ & Yes & Yes & No & No & -- \\
\hline CNTN4 & No & No & No & No & -- \\
\hline МСРН1 & No & No & No & No & -- \\
\hline$T N K S$ & No & No & No & No & -- \\
\hline SOX7 & Yes & No & No & No & -- \\
\hline GATA4 & No & Yes & No & No & -- \\
\hline
\end{tabular}

Ad, autosomal dominant; Ar, autosomal recessive, $\mathrm{Xl}$, $\mathrm{x}$-linked. 


\section{Discussion and Conclusions}

We have identified mutations in approximately half of genotyped patients known to have thoracic isomerism. All but two of these mutations were detected by genetic testing other than chromosome karyotype. Nearly four-fifths of the affected genes are known to be associated with either ciliary dyskinesia or isomerism in mice, with two-fifths known to be associated with these features in humans.

The most frequently affected gene was CFC1, which has been noted to be associated with ciliary abnormalities and isomerism in mice, as well as isomerism in humans. There have been 43 cases of $C F C 1$ mutations in humans reported, with $80 \%$ consistent with a diagnosis of left isomerism and the remainder with right isomerism. A majority was described as having a common atrioventricular junction, with double outlet right ventricle also reported in several patients. ${ }^{33,35-38}$ Thus far, very few descriptions have provided details of bronchial, pulmonary, or atrial appendage morphology. Our segregation of isomerism, therefore, was based on the aggregate of the other clinical features described. In this regard, previously reported cases have been associated mostly with presumed left isomerism, while the patients making up our current cohort were more likely to have right isomerism.

CFC1 mutations impair normal left-right patterning, as proteins encoded by $C F C 1$ are cofactors for NODAL-related signals. ${ }^{39}$ NODAL mutations were the second most frequently affected gene in our cohort. Such mutations are associated with ciliary dyskinesia and isomerism in mice, but only with isomerism in humans based on published reports. In one analysis, NODAL mutations were associated with a higher occurrence of pulmonary atresia, and $90 \%$ of the findings were most consistent with right isomerism. ${ }^{40}$ In the mouse, Nodal is known to play a role in formation of both endoderm and mesoderm, impacting left-right patterning. The gene encodes a protein that is part of the transforming growth factor beta family, and induces its coreceptor Cripto. Mice deficient in Nodal do not have a primitive streak, and thus fail to form any mesoderm. ${ }^{41-43}$ Likely due to the lack of mesoderm, there is an increase in endodermal formulation. Mice null for Nodal arrest their development during gastrulation, whereas hypomorphic mice have abnormalities in left-right patterning. ${ }^{44}$

In our cohort, we identified several patients with mutations of both $C F C 1$ and NODAL mutation. Those with NODAL mutations alone suffered increased morbidity, and those with a combined CFC1 and NODAL mutation had the longest hospitalization of any of our subgroups. To the best of our knowledge, this finding has not been previously described. It is, perhaps, related to underlying ciliary dyskinesia, particularly since need for mechanical ventilatory was increased in the setting of these mutations. We also identified mutations of CCDC39, DNAH11, NKX2.5, TBX1, ZIC3, $D N A A F$, SOX7, and GATA4 genes. All have previously been described to be associated with ciliary dyskinesia in either mice or humans, and in some cases both. ${ }^{16,45-63}$ We find it of significance, therefore, that a large proportion of affected genes are associated with not only isomerism, but also with ciliary dyskinesia. Previous studies have shown that over $40 \%$ of patients with isomerism also have ciliary dyskinesia. ${ }^{16}$ Nodal cilia in humans have a $9+0$ arrangement, lacking a central pair of microtubules. $^{64}$ These cilia rotate in a rotary pattern, rather than the whiplike pattern of the cilia more traditionally referred to as the motile cilia, which have a $9+2$ arrangement of microtubules. Studies have shown that mutations in genes affecting the central pair of microtubules can cause laterality abnormalities while mutations in genes affecting portions of the cilia other than the central pair do not affect laterality ${ }^{65,66}$ It is not only flow of embryonic fluid created by this rotary movement of cilia that affects laterality, however, but also impairment in ciliary sensory function. While the motile nodal cilia create the leftward flow of embryonic fluid, there is the requirement of downstream cilia to sense the flow, thus producing the co-called two-cilia hypothesis. ${ }^{67}$

Ciliary dyskinesia has effects outside of embryogenesis. Impairment in motile cilia can affect mucociliary clearance, which can increase sinupulmonary symptoms, and may mediate the need for increased mechanical ventilatory support. ${ }^{19}$ Impairment of motile cilia has also been implicated in the development of hydrocephalus in patients with isomerism. Impairment in sensory cilia may potentiate hepatic, renal, and splenic dysfunction, although this is yet to be delineated.

We recognize the limitations of our study, which was simply descriptive in demonstrating its inferred associations. We are not able directly to establish causality. While our data has demonstrated trends, future studies, with larger number of patients and additional genetic analysis, will be necessary to establish causality. Our study shows, nonetheless, that future studies focused on isomerism should contain detailed information about the patients, their clinical course, and the genetic data available. This will allow for all associations to be analyzed, and for trends to be noted.

We conclude that at least half of all patients with bodily isomerism are likely to have a mutation if analysed by microarray. Most genes identified in our patients are known to be associated with ciliary dyskinesia or isomerism. Identification of genes may, in the future, be predictive of clinical course.

Table 4. Comparison of gene mutations by genetic subgroup.

\begin{tabular}{|c|c|c|c|c|}
\hline Nodal mutation & CFCl mutation & $\begin{array}{l}\text { Mutation in Nodal } \\
\text { and CFC1 }\end{array}$ & $\begin{array}{l}\text { Other } \\
\text { mutation }\end{array}$ & $\begin{array}{l}\text { No mutation } \\
\text { identified }\end{array}$ \\
\hline $\begin{array}{l}\text { - Right isomerism (100\%) } \\
\text { - Right sided stomach } \\
\text { and left sided liver (100\%) } \\
\text { - Supraventricular } \\
\text { tachycardia (100\%) } \\
\text { - Increased length of hospitalization } \\
\text { for first cardiac intervention } \\
\text { (median } 134 \text { days) } \\
\text { - Increased length of hospitalization } \\
\text { for second cardiac intervention } \\
\text { (median } 134 \text { days) }\end{array}$ & $\begin{array}{l}\text { - Right isomerism (67\%) } \\
\text { - Sinus node dysfunction (67\%) } \\
\text { and supraventricular } \\
\text { tachycardia (33\%) }\end{array}$ & $\begin{array}{l}\text { - Left isomerism }(100 \%) \\
\text { - Right sided stomach and } \\
\text { left sided liver (100\%) } \\
\text { - Increased length of hospitalization } \\
\text { for first cardiac intervention } \\
\text { (median } 177 \text { days) } \\
\text { - Increased length of mechanical } \\
\text { ventilation after second } \\
\text { cardiac intervention (median } 95 \text { days) } \\
\text { - Increased length of hospitalization } \\
\text { for second cardiac intervention } \\
\text { (median } 235 \text { days) }\end{array}$ & $\begin{array}{l}\text { - Right isomerism }(100 \%) \\
\text { - Right or left sided stomach } \\
\text { with midline liver (57\%) } \\
\text { - Ectopic atrial tachycardia } \\
\text { (67\%) and supraventricular } \\
\text { tachycardia (33\%) }\end{array}$ & $\begin{array}{l}\text { - Right isomerism (92.3\%) } \\
\text { - Right sided stomach } \\
\text { and left sided liver (75\%) } \\
\text { - Atrial tachycardia (38\%) } \\
\text { and complete } \\
\text { atrioventricular block (38\%) }\end{array}$ \\
\hline
\end{tabular}


Dis 2015 [Epub ahead of print].

\section{References}

1. Loomba RS, Hlavacek AM, Spicer DE, Anderson RH. Isomerism or heterotaxy: which term leads to better understanding? Cardiol Young 2015:1-7.

2. Jacobs JP, Anderson RH, Weinberg PM, et al. The nomenclature, definition and classification of cardiac structures in the setting of heterotaxy. Cardiol Young 2007; 17:1-28.

3. Loomba R, Shah PH, Anderson RH. Fetal magnetic resonance imaging of malformations associated with heterotaxy. Cureus 2015;7:e269.

4. Loomba RS, Pelech AN, Shah PH, Anderson RH. Determining bronchial morphology for the purposes of segregating so-called heterotaxy. Cardiol Young 2015:1-13.

5. Partridge JB, Scott 0, Deverall PB, Macartney FJ. Visualization and measurement of the main bronchi by tomography as an objective indicator of thoracic situs in congenital heart disease. Circulation 1975;51:188-96.

6. Partridge J. The radiological evaluation of atrial situs. Clin Radiol 1979;30:95-103.

7. Van Mierop LH, Eisen S, Schiebler GL. The radiographic appearance of the tracheobronchial tree as an indicator of visceral situs. Am J Cardiol 1970;26:432-5.

8. Uemura H, Ho SY, Devine WA, et al.Atrial appendages and venoatrial connections in hearts from patients with visceral heterotaxy. Ann Thorac Surg 1995;60:561-9.

9. Uemura H, Ho SY, Devine WA, Anderson RH. Analysis of visceral heterotaxy according to splenic status, appendage morphology, or both. Am J Cardiol 1995;76:846-9.

10. van Praagh R, David I, Wright GB, van Praagh S. Large RV plus small LV is not single RV. Circulation 1980;61:1057-9.

11. Ivemark BI. Implications of agenesis of the spleen on the pathogenesis of conotruncus anomalies in childhood; an analysis of the heart malformations in the splenic agenesis syndrome, with fourteen new cases. Acta Paediatr Suppl 1955;44:7-110.

12. Van Mierop L, Gessner I, Schliebler G. Asplenia and polysplenia syndrome. Birth Defects 1972;1:74-82.

13. Smith A, Ho SY, Anderson RH, et al. The diverse cardiac morphology seen in hearts with isomerism of the atrial appendages with reference to the disposition of the specialised conduction system. Cardiol Young 2006;16:437-54.

14. Loomba RS, Willes RJ, Kovach JR, Anderson RH. Chronic arrhythmias in the setting of heterotaxy: differences between right and left isomerism. Congenit Heart
15. Loomba RS, Aggarwal S, Gupta N, et al. Arrhythmias in adult congenital patients with bodily isomerism. Pediatr Cardiol 2015 [Epub ahead of print].

16. Nakhleh N, Francis R, Giese RA, et al. High prevalence of respiratory ciliary dysfunction in congenital heart disease patients with heterotaxy. Circulation 2012;125:2232-42.

17. Blum M, Vick P. Left-right asymmetry: cilia and calcium revisited. Curr Biol 2015;25:R205-7.

18. Hildebrandt F, Benzing T, Katsanis $\mathrm{N}$. Ciliopathies. N Engl J Med 2011;364:1533-43.

19. Garrod AS, Zahid M, Tian X, et al. Airway ciliary dysfunction and sinopulmonary symptoms in patients with congenital heart disease. Ann Am Thorac Soc 2014;11:1426-32.

20. D’Angelo A, Franco B. The primary cilium in different tissues-lessons from patients and animal models. Pediatr Nephrol 2011;26:655-62.

21. Abdel-Bari W, Sorenson GD. Ciliated cells in the spleen of adult rats. Anat Record 1965;152:481-5.

22. Marley A, von Zastrow M. A simple cellbased assay reveals that diverse neuropsychiatric risk genes converge on primary cilia. PloS One 2012;7:e46647.

23. Li Y, Garrod AS, Madan-Khetarpal S, et al. Respiratory motile cilia dysfunction in a patient with cranioectodermal dysplasia. Am J Med Genet Part A 2015;167:2188-96.

24. Shapiro AJ, Tolleson-Rinehart S, Zariwala MA, et al. The prevalence of clinical features associated with primary ciliary dyskinesia in a heterotaxy population: results of a web-based survey. Cardiol Young 2015;25:752-9.

25. Hynes AM, Giles RH, Srivastava S, et al. Murine Joubert syndrome reveals Hedgehog signaling defects as a potential therapeutic target for nephronophthisis. Proc Natl Acad Sci U S A 2014;111:9893-8.

26. Hurd TW, Hildebrandt F. Mechanisms of nephronophthisis and related ciliopathies. Nephron Exper Nephrol 2011;118:e9-14.

27. Rock N, McLin V. Liver involvement in children with ciliopathies. Clin Res Hepatol Gastroenterol 2014;38:407-14.

28. Huang BQ, Masyuk TV, Muff MA, et al. Isolation and characterization of cholangiocyte primary cilia. Am J Physiol Gastroint Liver Physiol 2006;291:G500-9.

29. Louvi A, Grove EA. Cilia in the CNS: the quiet organelle claims center stage. Neuron 2011;69:1046-60.

30. Masyuk AI, Masyuk TV, LaRusso NF. Cholangiocyte primary cilia in liver health and disease. Develop Dynam 2008;237:2007-12.

31. Masyuk AI, Masyuk TV, Splinter PL, et al.
Cholangiocyte cilia detect changes in luminal fluid flow and transmit them into intracellular $\mathrm{Ca} 2+$ and cAMP signaling. Gastroenterol 2006;131:911-20.

32. Chu AS, Russo PA, Wells RG. Cholangiocyte cilia are abnormal in syndromic and non-syndromic biliary atresia. Modern Pathol 2012;25:751-7.

33. Bamforth SD, Braganca J, Farthing CR, et al. Cited2 controls left-right patterning and heart development through a Nodal-Pitx2c pathway. Nature Genet 2004;36:1189-96.

34. Meno C, Shimono A, Saijoh Y, et al. lefty-1 is required for left-right determination as a regulator of lefty-2 and nodal. Cell 1998;94:287-97.

35. Selamet Tierney ES, Marans Z, Rutkin MB, Chung WK. Variants of the CFCl gene in patients with laterality defects associated with congenital cardiac disease. Cardiol Young 2007;17:268-74.

36. Cao R, Long F, Wang L, et al. Duplication and deletion of CFCl associated with heterotaxy syndrome. DNA Cell Biol 2015;34:101-6.

37. Wang B, Wang J, Liu S, et al. CFC1 mutations in Chinese children with congenital heart disease. Int $\mathrm{J}$ Cardiol 2011;146:86-8.

38. Davit-Spraul A, Baussan C, Hermeziu B, et al. CFCl gene involvement in biliary atresia with polysplenia syndrome. J Pediatric Gastroenterol Nutr 2008;46:111-2.

39. Gritsman K, Zhang J, Cheng S, et al. The EGF-CFC protein one-eyed pinhead is essential for nodal signaling. Cell 1999;97:121-32.

40. Mohapatra B, Casey B, Li H, et al. Identification and functional characterization of NODAL rare variants in heterotaxy and isolated cardiovascular malformations. Hum Mol Genet 2009;18: 861-71.

41. Conlon FL, Lyons KM, Takaesu N, et al. A primary requirement for nodal in the formation and maintenance of the primitive streak in the mouse. Develop 1994;120:1919-28.

42. Conlon FL, Barth KS, Robertson EJ. A novel retrovirally induced embryonic lethal mutation in the mouse: assessment of the developmental fate of embryonic stem cells homozygous for the 413.d proviral integration. Develop 1991;111:969-81.

43. Lowe LA, Supp DM, Sampath K, et al. Conserved left-right asymmetry of nodal expression and alterations in murine situs inversus. Nature 1996;381:158-61.

44. Lowe LA, Yamada S, Kuehn MR. Genetic dissection of nodal function in patterning the mouse embryo. Develop 2001;128: 1831-43.

45. Lucas JS, Adam EC, Goggin PM, et al. Static respiratory cilia associated with mutations 
in Dnahc11/DNAH11: a mouse model of PCD. Hum Mutat 2012;33:495-503.

46. Schwabe GC, Hoffmann K, Loges NT, et al. Primary ciliary dyskinesia associated with normal axoneme ultrastructure is caused by DNAH11 mutations. Hum Mutat 2008;29:289-98.

47. Pifferi M, Michelucci A, Conidi ME, et al. New DNAH11 mutations in primary ciliary dyskinesia with normal axonemal ultrastructure. Eur Respir J 2010;35:1413-6.

48. Knowles MR, Leigh MW, Carson JL, et al. Mutations of DNAH11 in patients with primary ciliary dyskinesia with normal ciliary ultrastructure. Thorax 2012;67:433-41.

49. Bartoloni L, Blouin JL, Pan Y, et al. Mutations in the DNAH11 (axonemal heavy chain dynein type 11) gene cause one form of situs inversus totalis and most likely primary ciliary dyskinesia. Proc Natl Acad Sci U S A 2002;99:10282-6.

50. Antony D, Becker-Heck A, Zariwala MA, et al. Mutations in CCDC39 and CCDC40 are the major cause of primary ciliary dyskinesia with axonemal disorganization and absent inner dynein arms. Hum Mutat 2013;34:462-72.

51. Blanchon S, Legendre M, Copin B, et al. Delineation of CCDC39/CCDC40 mutation spectrum and associated phenotypes in primary ciliary dyskinesia. J Medical Genet 2012;49:410-6.

52. Merveille AC, Davis EE, Becker-Heck A, et al. CCDC39 is required for assembly of inner dynein arms and the dynein regulatory complex and for normal ciliary motility in humans and dogs. Nature Genet 2011;43:72-8.

53. Izumi K, Noon S, Wilkens A, Krantz ID. NKX2.5 mutation identification on exome sequencing in a patient with heterotaxy. Eur J Med Genet 2014;57:558-61.

54. D'Alessandro LC, Casey B, Siu VM. Situs inversus totalis and a novel ZIC3 mutation in a family with X-linked heterotaxy. Congenit Heart Dis 2013;8:E36-40.

55. Wessels MW, Kuchinka B, Heydanus R, et al. Polyalanine expansion in the ZIC3 gene leading to X-linked heterotaxy with VACTERL association: a new polyalanine disorder? J Med Genet 2010;47:351-5.

56. Ma L, Selamet Tierney ES, Lee T, et al. Mutations in ZIC3 and ACVR2B are a common cause of heterotaxy and associated cardiovascular anomalies. Cardiol Young 2012;22:194-201.

57. Bamford RN, Roessler E, Burdine RD, et al. Loss-of-function mutations in the EGFCFC gene $\mathrm{CFCl}$ are associated with human left-right laterality defects. Nature Genet 2000;26:365-9.

58. Bedard JE, Haaning AM, Ware SM. Identification of a novel ZIC3 isoform and mutation screening in patients with heterotaxy and congenital heart disease. PloS One 2011;6:e23755.

59. Ware SM, Peng J, Zhu L, et al. Identification and functional analysis of ZIC3 mutations in heterotaxy and related congenital heart defects. Am J Hum Genet 2004;74:93-105.

60. Haaning AM, Quinn ME, Ware SM.
Heterotaxy-spectrum heart defects in Zic3 hypomorphic mice. Pediatr Res 2013;74:494-502.

61. Tzschach A, Hoeltzenbein M, Hoffmann K, et al. Heterotaxy and cardiac defect in a girl with chromosome translocation $t(X ; 1)(q 26 ; p 13.1)$ and involvement of ZIC3. Eur J Hum Genet 2006;14:1317-20.

62. Ware SM, Harutyunyan KG, Belmont JW. Heart defects in X-linked heterotaxy: evidence for a genetic interaction of Zic3 with the nodal signaling pathway. Develop Dynam 2006;235:1631-7.

63. Chung B, Shaffer LG, Keating S, et al. From VACTERL-H to heterotaxy: variable expressivity of ZIC3-related disorders. Am J Med Genet Part A 2011;155A:1123-8.

64. Bellomo D, Lander A, Harragan I, Brown NA. Cell proliferation in mammalian gastrulation: the ventral node and notochord are relatively quiescent. Develop Dynam 1996;205:471-85.

65. Olbrich H, Schmidts M, Werner C, et al. Recessive HYDIN mutations cause primary ciliary dyskinesia without randomization of left-right body asymmetry. Am J Hum Genet 2012;91:672-84.

66. Lechtreck KF, Delmotte P, Robinson ML, et al. Mutations in Hydin impair ciliary motility in mice. J Cell Biol 2008;180:633-43.

67. McGrath J, Somlo S, Makova S, et al. Two populations of node monocilia initiate leftright asymmetry in the mouse. Cell 2003;114:61-73. 